\title{
Physical and chemical characteristics of some Nigerian wheat (Triticum aestivum $\mathbf{L}$ ) bulgurs
}

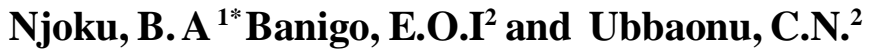 \\ ${ }^{1}$ Chemistry Department, Alvan Ikoku College of Education, Owerri. \\ ${ }^{2}$ Department of Food Science and Technology. Federal University of Technology, Owerri, Nigeria \\ *Address for correspondence E-mail : adimnkaru@yahoo.com
}

ABSTRACT

\begin{abstract}
The physical and chemical composition of Nigerian wheat varieties, Florence Aurore 8193, Pavon 76, Siete Cerros and Seri 82 and bulgur made from them were studied. The physical characteristics such as kernel density, test weight, 100-kernel weight, grain hardness were about the same in the wheat varieties. Mineral and vitamin contents in bulgur were higher than in wheat. The protein content of bulgur samples ranged from 10.61 to $10.54 \%$ as compared to a range of 12.12 to $12.69 \%$ found in the wheat varieties. Other chemical components (crude fat, crude fibre, ash, simple sugars, total starch) of the different wheat varieties were similar, but there was significant $(\mathrm{p}<0.05)$ reduction
\end{abstract}

in crude fat, crude fibre and ash contents in the bulgur samples due to dehulling. The amylose content of the wheat varieties were similar in the range of $12.25 \%$ to $12.85 \%$ but were significantly $(\mathrm{p}<0.05)$ higher in the bulgur samples $(16.03 \%$ - 16. 28\%). The simple sugars content, total starch, carbohydrate and caloric values in the wheat varieties were not significantly different from the values in the bulgur samples made from them. Bulgur is a whole grain product, low in fat, fibre and ash and high in protein.

Key words: Nigerian wheat burlgur, physico-chemical characteristic.

\section{INTRODUCTION}

$\mathrm{B}_{\mathrm{p}}^{\mathrm{u}}$ ulgur is a steamed and dried whole-wheat product which, may be dehulled or undehulled. It is an ancient Middle East staple food, which was referred to as Arisah (a Hebrew word) in the Old Testament of the Holy Bible (Ezekiel 44: 31, Nehemiah 10: 37), (Aykroyd and Doughty, 1970). Nutritionally, it resembles whole wheat more closely than refined white wheat flour because the nutritive value of wheat remains relatively unaltered when bulgur is produced.

The cultivation of wheat in Nigeria dates back to the 16th century though it was grown on small scales mainly in the Sahel and Sudan Savanna Zones (Olugbemi et al, 1992). The varieties of wheat grown in Nigeria include Siete Cerros, Florence Aurore 8193, Pavon 76 and Seri 82 and these were among the varieties released by the Institute of Agricultural Research, Zaria (Olugbemi, 1990).

The local wheat grown in Nigeria was originally processed in households into various local dishes such as "Kuli-Kuli". "Kasai", "Pankai", "Alikaki". "Dambu", "Danwake", "Nakiya", and "Dashishi". Betchart (1988) suggested that creating increased consumer interest and desire for wheat foods and promoting awareness of the healthful qualities of wheat foods, along with the development of new and attractive wheat-food products could contribute to increased consumption of wheat, particularly when the staple foods are starchy roots and fruits low in protein as is the case in the South-Eastern states of Nigeria. 
The study was conducted to determine the physical and chemical characteristics of bulgur made from Nigerian wheat varieties so as to fit it into more local dishes and food applications and thereby stimulate demand and_cultivation of wheat locally.

\section{MATERIALS AND METHODS}

Four Nigerian wheat varieties Florence Aurore 8193, Pavon 76, Siete Cerros and Seri 82 obtained from the Institute for Agricultural Research, Zaria, were processed to bulgur samples in this study by adaptation of local food processing methods involving manual cleaning by sorting, washing and parboiling (20min), followed by steaming (20 min), drying $\left(60^{\circ} \mathrm{C}\right.$ for $\left.3 \mathrm{~h}\right)$ and machine dehulling. For physical properties, the test weight (bulk density) of the wheat varieties were determined as described by Kikuchi et al (1982); kernel density was determined as described by Arnold et al (1977); and 1000 - kernel weight was determined according to Hilliard and Daynard (1974) procedure. The procedure described by Pomeranz et al (1985) using Stenvert Hardness Tester MHM; type 5 equipment was applied in determining the hardness of wheat and bulgur samples. The milling yields of wheat and bulgur samples were analysed according to the procedure of Paulsen and Hills (1985) while particle size distributions were done using a Tyler Ro - Tap Mechanical Shaker as described by Pomeranz et al (1985). In chemical analysis, the levels of folic acid, niacin and carotenoid pigments in the samples were determined by the AOAC (1990) methods. The mineral composition was determined by ICP tests. These analyses were conducted at ADPEN Laboratories INC, Florida 32224 USA. Protein, fat, ash, crude fibre, and moisture contents of the wheat and bulgur were determined using the standard methods of the American Association of Cereal Chemists (AACC, 1984). Carbohydrate was calculated by difference, while caloric values were calculated using the average values obtained for fat, protein and carbohydrates.
Free sugars and starch contents were determined as described by Kalenga et al (1981) and Joslyn (1970). Amylose content was determined according to the methods described by Juliano (1971) and Williams et al (1958) with the aid of a Spectrophotometer.

\section{RESULTS AND DISCUSSION}

The test weights (Bulk density) of the wheat grains ranged from $0.76 / \mathrm{ml}$ for Seri 82 to $0.83 \mathrm{~g} / \mathrm{mI}$ for Pavon 76 (Table 1), and there were no significant differences $(\mathrm{p}<0.05)$ in these weights for the different wheat samples. Dick and Matsuo (1988) had reported that the higher the test weight the greater the percentage endosperm. Test weight is a measure of kernel soundness and fully mature, plump kernels undamaged by disease or

by the environment are high in test weight. In Italy, millers buying domestic durum wheat specify a test weight range of $0.78-0.82 \mathrm{~g} \backslash \mathrm{ml}$. In studies involving common wheat (soft, hard, spring, winter), no correlation was found between flour yield and test weight (Dick and Matsuo, 1988) but durum wheat samples (which have a large range in test weight) showed a significant correlation between semolina yield and test weight. Kernel density ( $\mathrm{g} \backslash \mathrm{ml})$ ranged from 1.5 in Siete Cerros to 1.13 in Seri 82, with Pavon 76 and Florence Aurore 8193 having a similar value (1.33). Irvine (1961) had reported that kernel density remained essentially constant at 1.43 $\mathrm{g} \mathrm{cm}-3$ in hard red spring wheat of same moisture content and test weights ranging from 0.67 to $0.84 \mathrm{~g} /$ $\mathrm{ml}$ and that density was affected by the relative composition of starch, protein, oil and water in the grains. The 1000-kernel weight values for the grain in highest for Pavon 76 (38.0g) followed by Florence Aurore 8193 (35.6g), Seri 82 (33.3g) and Siete Cerros (29.81g). Both Irvine (1979) and Matsuo and Dexter (1980) reported that kernel weight ranged between 37.0 and $43.0 \mathrm{~g} / 1000$ kernels in wheat; with a corresponding range in test weight from 0.72 to $0.86 \mathrm{~g} / \mathrm{ml}$. These values were within the 
ranges obtained for the Nigerian wheat varieties in this study (Table 1). Grain hardness as measured by the Stenvert Hardness Tester was not significantly different $(p<0.05)$ for all the wheat samples studied, the mean value being $36 \pm 2 \mathrm{sec}$. Kernel hardness as reported by Kent (1984), indicated the extent of internal cracks and fissures which could lead to losses during processing and storage.

Dick and Matsuo (1988) reported that kernel hardness was desirable for production of semolina and the same could be said of bulgur. Both Tipples (1969) and Barlow et al (1973) reported that in soft wheat (of low protein content) strength of adhesion between the protein matrix and starch granules is low. Similarly Stenvert and Kingswood (1977) found that the strength with which the protein matrix physically traps the starch granules is also low. The time to grind $20 \mathrm{~g}$ sample as determined by the Stenvert Hardness Tester averaged 34.3 secs for bulgur samples (Table 2). The average milling yield of the different wheat samples studied was 91.96 \pm $0.3 \mathrm{~g}$ per $100 \mathrm{~g}$ sample milled and according to Bhattacharya et al (1992), milling yield was often associated with the hardness of grains. The milling yield for $100 \mathrm{~g}$ samples of bulgur ranged from $86.25 \mathrm{~g}$ to $89.35 \mathrm{~g}$. Particle size analysis showed major fractions as $<500 \mu \mathrm{m}$ in the bulgur samples and more than $50 \%$ being less than $500 \mu \mathrm{m}$. It was observed that bulgur from Pavon 76 wheat had the highest grinding time $(34.46 \mathrm{sec})$, the lowest milling yield $(86.25 \mathrm{~g})$ and the highest fraction that is $<500 \mu \mathrm{m}$ (27.00\%). A milling loss of $11.3 \%$ was observed for the bulgur sample. Sierre (2003) reported that different particle sizes as well as whole kernel bulgur exhibited different textures and properties for varieties of food applications.

Pavon 76 wheat was superior to Seri 82 wheat in mineral and vitamin composition (Table 3) except for copper which was lower in Pavon 76 wheat $(10.6 \mathrm{mg} / \mathrm{kg})$ than in Seri 82 wheat $(11.6 \mathrm{mg} / \mathrm{kg})$. Except for iron which had a higher value $(81.1 \mathrm{mg} /$ $\mathrm{kg}$ ) in Pavon 76 wheat than in its bulgur $(75.5 \mathrm{mg} /$ $\mathrm{kg}$; a decrease of $6.91 \%$ ), other minerals and vitamins were greater in bulgur than in wheat; the highest percentage increase being for molybdenum $(39.61 \%)$ followed by zinc $(34.72 \%)$ and the least was niacin (4.02\%). Similarly except for folic acid which was higher in Seri 82 wheat $(0.28 \mathrm{ppm})$ than in its bulgur $(0.21 \mathrm{ppm})$, a decrease of $24.64 \%$, all the other vitamins and minerals were greater in its bulgur than in the wheat: highest percentage increase being for zinc $(156.38 \%)$ followed by copper $(134.48 \%)$ and iron $(92.64 \%)$, the least being magnesium (5.99\%). As in rice, soluble nutrients, minerals and vitamins have actually moved into the endosperm during the parboiling and steaming processes. Even Pence et al (1964) reported that values of iron and calcium were greater in bulgur than in wheat. This result is in contrast to looses of less than

$10 \%$ in folic acid, vitamin B6, thiamine, riboflavin and pantothenic acid reported by Fellers (1974). Ferrel et al (1966) reported that $90 \%$ of thiamine and riboflavin was retained in the bulgur produced by the continuous atmospheric process.

The protein content of the wheat samples in the study, ranged from $12.12 \%$ to $12.67 \%$ (Table4). This level of protein content is appreciated because the major sources of protein in the average diets of Nigerians are primarily grains such as wheat. The range of protein content in the bulgur samples was from $10.6 \%$ to $10.84 \%$. The reduction is attributed to both slight leaching and duhulling losses. There were similar reductions in crude fat content in the bulgur samples due to the moist - heat treatment and dehulling losses. Just as would be expected, removal of hulls reduced the crude fibre and ash contents of bulgur, but the values for fat, fibre and ash contents were sufficiently larger than those normally found in flour or wheat endosperm to indicate that a fairly large part of the bran nutrients is retained in bulgur (Haley and Pence, 1960). There were relative increases in the values of amylose contents from a range of $12.25 \%$ to $12.55 \%$ in the 
wheat varieties to a range of $16.03 \%$ to $16.28 \%$ in the bulgur which may be attributed to removal of hulls and reduction in fibre, ash and fat that thus diluted the value of amylose for bulgur samples. The total starch contents and caloric values seemed not to be affected by the moist-heat treatment and dehulling process.

The U.S Department of Agricultural Research Service (USDA, ARS, 1998) has a specification of a minimum content of $9.3 \%$ protein, $2.3 \%$ fibre and $3.0 \%$ ash and those values are within the range obtained in this study. The low- fibre-bulgur produced in the study would be desirable since the consumers tend to regard high fibre bulgur as ' $h a r d$ ' or 'rough' rice (Banigo and Omololu, 1970). The results of this study agree with Davis (1992), who reported that bulgur offered whole grain nutrients, was high in carbohydrates and very low in fat. It is known that diets rich in whole grain food and low in total fat may help reduce the risk of heart disease and cancer (D.S, FDA, 1999). The consumption of bulgur made from Nigeria wheat would supplement low protein foods such as cassava, yam and cocoyam mostly eaten in the South East Zone ,of Nigeria and thereby stimulate cultivation of wheat in Nigeria.

\section{CONCLUSION}

The whole grain bulgur produced from local wheat is low in fat, fiber and ash. The mineral, vitamin and amylose contents in bulgur were higher that and wheat. The level of protein content is high and is appreciated since the major sources of protein in the average diets of Nigerians are primarily grains, such as wheat. 


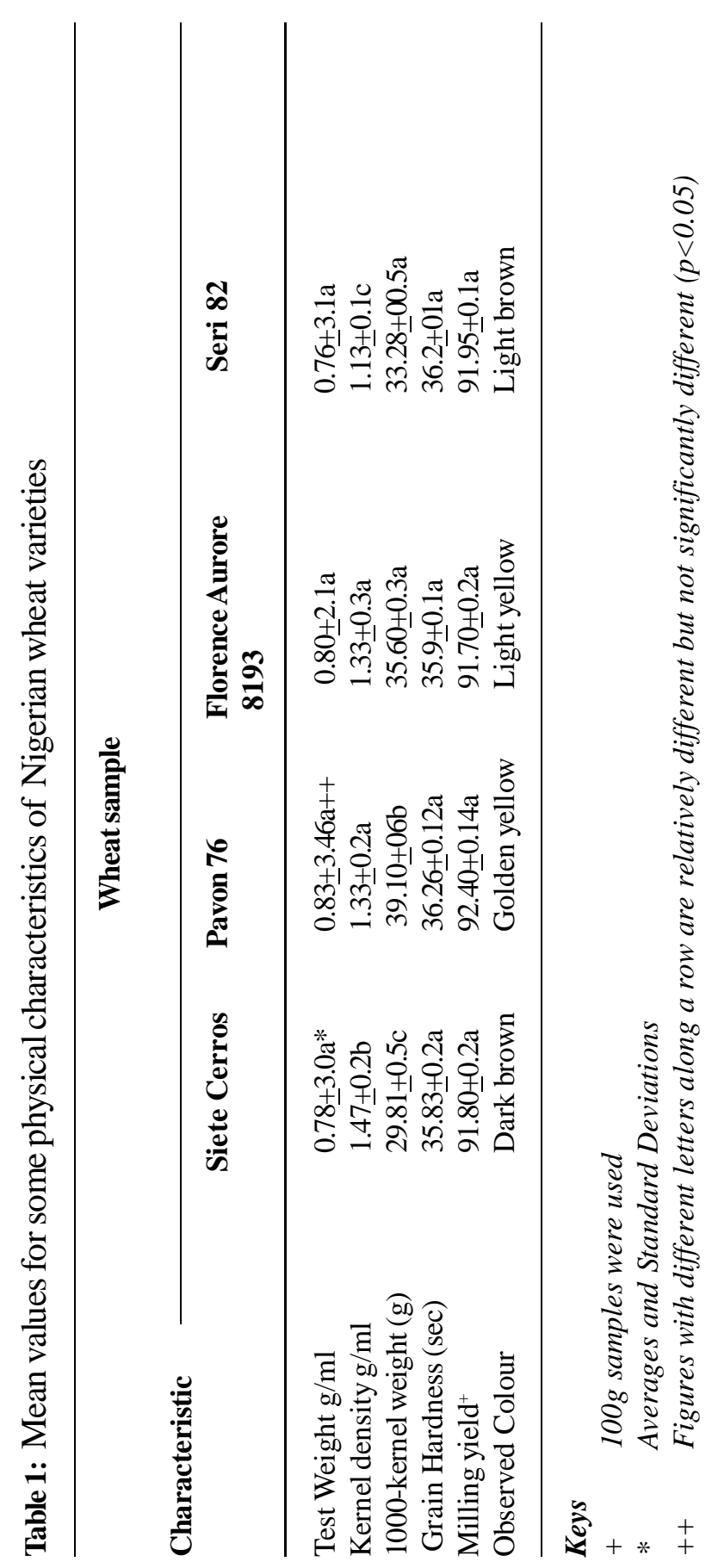




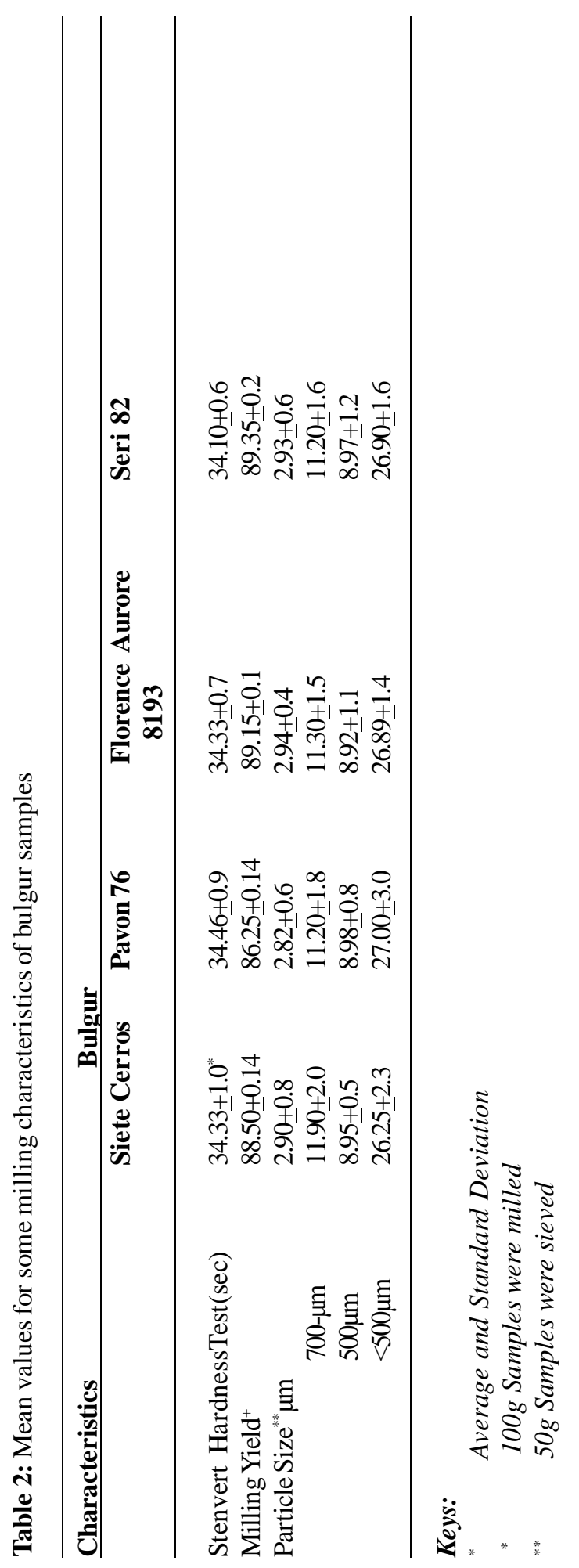


Table 3: Mineral and vitamin composition of wheat and bulgur samples*

\begin{tabular}{lllll} 
& \multicolumn{2}{c}{ Wheat } & Bulgur \\
\hline Component & Pavon 76 & Seri 82 & Pavon 76 & Seri 82 \\
\hline Folic Acid (ppm) & 0.289 & 0.280 & $0.313(8.30)$ & $0.211(24.64)^{+}$ \\
Niacin $(\mathrm{ppm})$ & 64.6 & 54.40 & $67.2(4.02)$ & $60.1(10.48)$ \\
Copper $(\mathrm{mg} / \mathrm{kg})$ & 10.6 & 11.60 & $13.2(24.53)^{+}$ & $27.2(134.48)$ \\
Zinc $(\mathrm{mg} / \mathrm{kg})$ & 43.2 & 29.80 & $58.2(34.72)$ & $76.4(156.38)$ \\
Iron $(\mathrm{mg} / \mathrm{kg})$ & 81.1 & 57.10 & $75.5(6.91)$ & $110(92.64)$ \\
Magnesium $(\mathrm{mg} / \mathrm{kg})$ & 1310 & 1180 & $1460(11.45)$ & $1250(5.9)$ \\
Molybdenum $(\mathrm{mg} / \mathrm{kg})$ & 0.659 & $<0.50$ & $1460(39.61)$ & $<0.50$ \\
Cobalt $(\mathrm{mg} / \mathrm{kg})$ & $<0.50$ & $<0.50$ & - & - \\
Lithium $(\mathrm{mg} / \mathrm{kg})$ & $<2.5$ & $<2.5$ & - & - \\
\hline
\end{tabular}

* $\quad$ Figures in parenthesis are percentage increases

$+\quad$ Percentage decreases. 


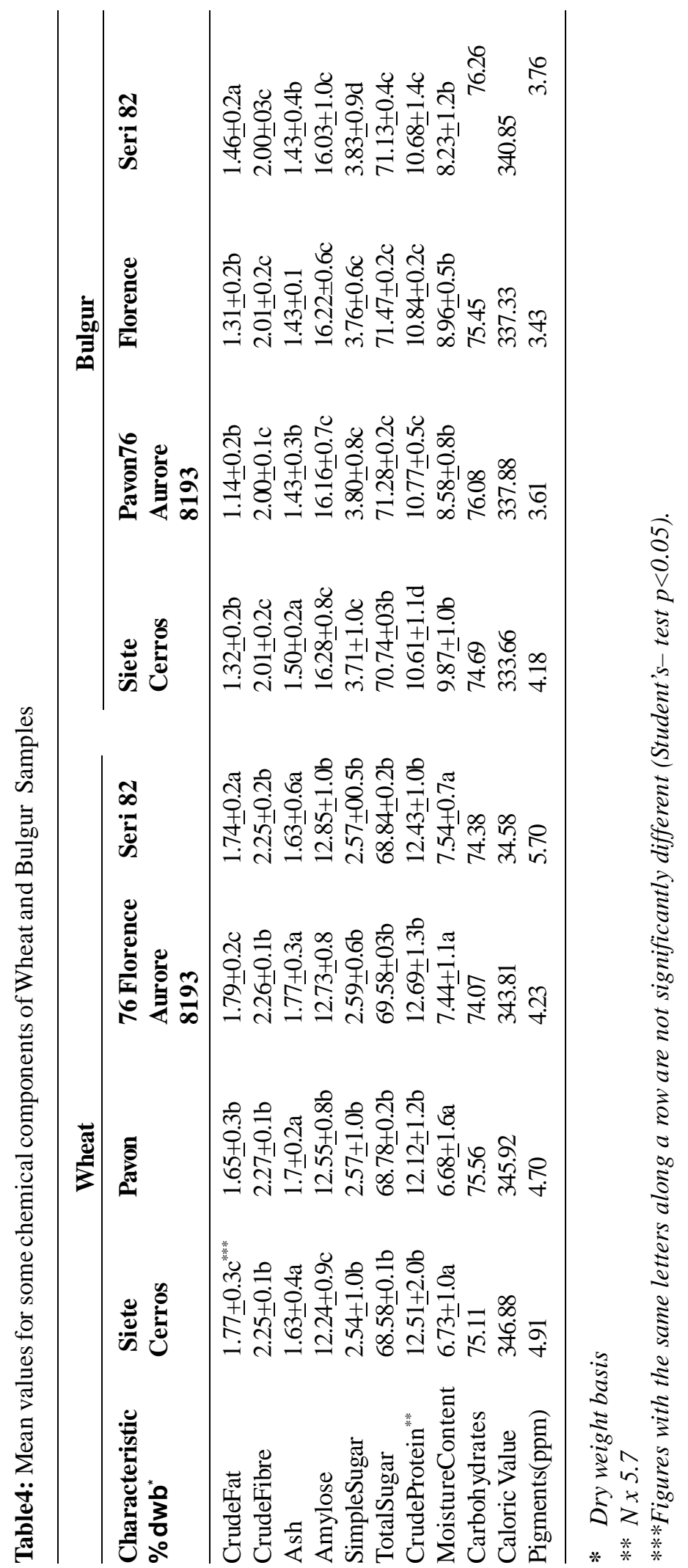




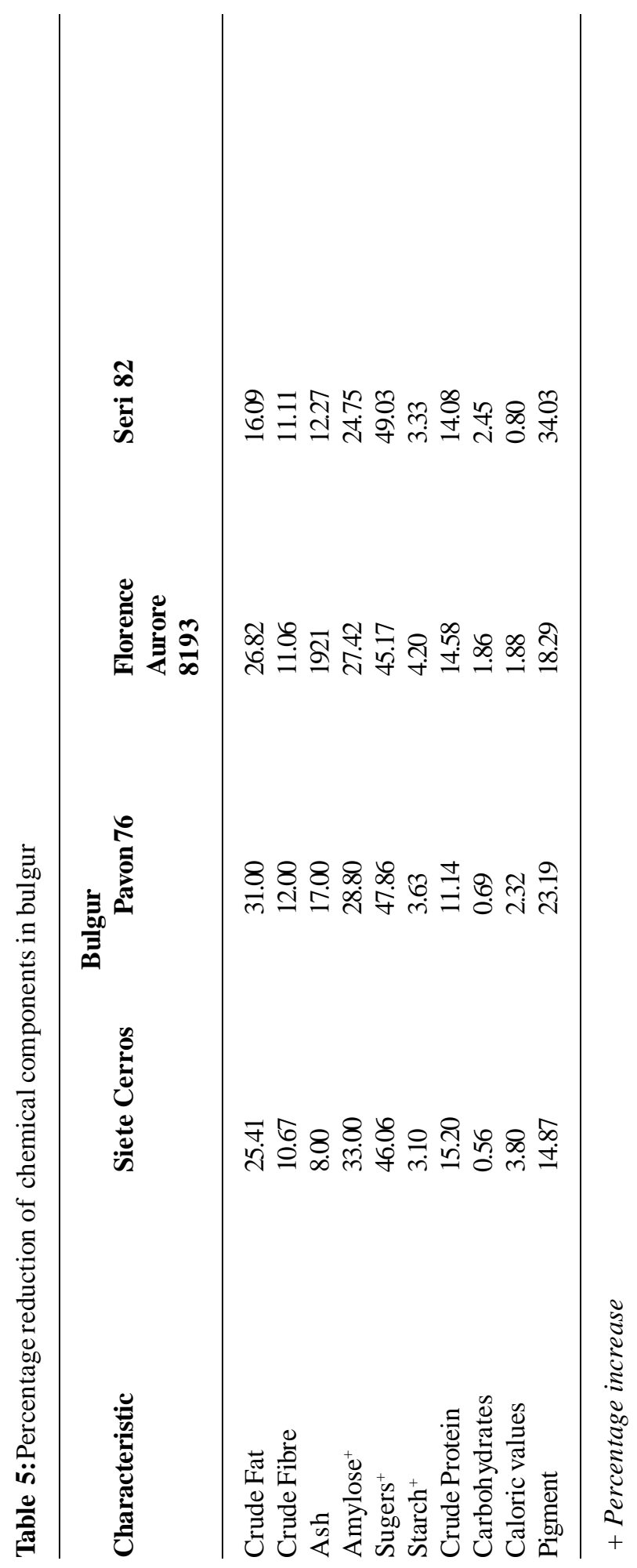




\section{REFERENCES}

American Association of Cereal Chemists, (1984). Approved Methods of AACC, St. Paul, Minnesota, USA.

Arnold, J.M., Bauman, L. and Aycock H.S. (1977), Interrelation among protein, lysine, oil, certain mineral elements concentrations and physical kernel characteristics in maize populations, Crop Science 17:421.

Aykroyd, W.R. and Doughty I. (1970): Wheat in Human Nutrition. F.A.O. Rome.

Banigo, E.O.I.and Omololu A. (1970).The acceptability of new protein -rich foods in the waraffected areas of Nigeria. Proceedings of Seminar on Protein Food Promotion, U.S. Org. Mission to Thailand, Bangkok, Thailand Part l, p9.

Barlow, K.K., Buttrose, M.S., Simmonds, D.H. and Vesk, M. (1973). The nature of the starch-protein interface in wheat endosperm. Cereal Chem. 50, 443-454.

Betschart, A. A(1998). Nutritional Quality of Wheat and Wheat Foods: In Wheat: Chemistry and Technology Vol. II. Ed. Pomeranz, Y. American Association of Cereal Chemists Inc.St. Paul Minnesota, U.S.A.

Davis, S. (1992) Bulgur comes into its own. Sch. Food Ser. J. 46(6).12.

Dick,J. W. and Matsuo, R. R. (1988). Durum wheat Pasta Products. In: Wheat, Chemistry and Technology. 3rd Ed. Vol.11. Pomeranz Y. American Association of Cereal Chemists Inc. St. Paul Minnesota. USA.

Harley, W.C. and J.W. Pence (1960). Bulgur, an Ancient Wheat Food. Cereal Science Today 5: 203207.
Hilliard, J.H. and Daynard T.T.(1974). Starch content, test weight and other quality parameters of corn produced in different areas of Ontario. Crop Sci 14: 546.

Irvine, G.N. (1961). Annual Report. Grain Research Laboratory, Winnipeg.

Irvine, G.N. (1979); Durum wheat quality. Comments on the international collaboration test. Proceeding, Int'l Symposium Rome.

Joslyn, A.M. (1970) Methods in Food Analysis. 2nd Ed. ASeries of Monographs. Academic Press, N.Y. p542-559.

Kalenga, K; Hood L.F; and Vansoest PJ.(1981) Characterization of Starch and fiber of Banana Fruit. J. Fd Sci Agric 46(6): 1885-1890.

Kent, N.L. (1984) Technology of Cereals with special reference to wheat, 3rd Ed. Pergamon Press, 43-63.

Kikuchi, K, Takatsuji, L, Tokunda, M., and Miyake K. (1982). Properties and uses of horny and floury endosperms of Corn. J. Food Sci 47:16, 87.

Matsuo, A. and Dexter, J.E. (1980) Relationship between some durum wheat physical characteristics and semolina milling properties. Can. J. Plant Sci. $60 ; 49-53$.

Olugbemi, L.B. (1990) Major constraints and remedies to wheat production in Nigeria. First National Conference on Wheat Production, Processing and Utilization in Nigeria. Maiduguri.

Olugbemi, L.B. Orakwue, F.C. and Yayock, J. Y. (1992). Developing Appropriate wheat varieties for the Tropics. Nigerian Experience. Proceedings of 
the Workshop on Recent Developments In Cereal Production in Nigeria, IITAIbadan.

Paulsen, M.R. and Hills L.D. (1985), Corn quality factors affecting dry milling performance. Journal of AgriculturalEngineering Research 31:255-263.

Pomeranz, Y; Czuchajowsko,Z; Martin, C.R;' and F.S. Lai (1985). Determination of Corn Hardness by the Stenvert Hardness Tester. Cereal Chem. 62(a): 108-112.

Stenvert, N.L. and Kingswood, K. (1977). The Influence of the Physical Structure of the Protein Matrix on Wheat Hardness. J. SciFd. Agric 28 (1): 11-19.

Thomas S, D J., and Atwell, W.A. (1999) Starches. Eagen Press Handbook Series. St. Paul Minnesota, U.S.A.
Tipples, K.H. (1969). The Relation of Starch Damage to the Baking Performance of Flour. Bakers' Dig. 43 (6): 28-32, 44.

USDA: ARS (1998) USDA Nutrient Database Release 12, Laboratory Home Page. (http:// www.na!.uscta .9ov/fnlbiloodcomp).

Williams, U.R., Wu, W; Tsai, H.Y. and Bates, H.G. (1958). Varietal Differences In Amylose content of Rice starch. Journal of Agriculture and Food Chemistry 6: 47-48. 